\title{
Fungicidal Activity of Plant Volatile Compounds for Controlling Monilinia laxa in Stone Fruit
}

Fiorella Neri, Marta Mari, Stefano Brigati, and Paolo Bertolini, Criof, Department of Protection and Improvement of Agricultural Food Products, Alma Mater Studiorum, University of Bologna, via Gandolfi, 19, 40057 Cadriano di Granarolo Emilia, Bologna, Italy

\begin{abstract}
Neri, F., Mari, M., Brigati, S., and Bertolini, P. 2007. Fungicidal activity of plant volatile compounds for controlling Monilinia laxa in stone fruit. Plant Dis. 91:30-35.

Nine plant-volatile compounds were tested for their activity against Monilinia laxa, the cause of brown rot in stone fruit. In vitro trials on conidial germination and mycelial growth showed a consistent fungicidal activity of trans-2-hexenal, carvacrol, and citral, whereas transcinnamaldehyde, hexanal, (-)-carvone, eugenol, 2-nonanone, and $p$-anisaldehyde exhibited a progressively lower inhibition. The best inhibitor of conidial germination was trans-2-hexenal (effective dose for 50 and $90 \%$ inhibition $\left[\mathrm{ED}_{50}\right.$ and $\left.\mathrm{ED}_{95}\right]=7.53$ and $9.4 \mu \mathrm{l} /$ liter, respectively; minimal inhibitory concentration $[\mathrm{MIC}]=12.3 \mu \mathrm{l} /$ liter], whereas carvacrol was the best inhibitor of mycelial growth $\left(\mathrm{ED}_{50}\right.$ and $\mathrm{ED}_{95}=2$ and $3.4 \mu \mathrm{l} /$ liter, respectively; $\mathrm{MIC}=6.1 \mu \mathrm{l} /$ liter). The three most active compounds in in vitro studies also were tested in vivo as postharvest biofumigants. The best control of brown rot was with trans-2-hexenal (efficacy ranging from 46.2 to $80.3 \%$, depending on cultivar), whereas citral and carvacrol resulted in a lower efficacy of 40 and $32.9 \%$, respectively. Fumigation with trans-2-hexenal at concentrations that stopped decay did not cause any visible disorders to plum, whereas it was phytotoxic to apricot, peach, and nectarine and produced off-odors or off-flavors in all species of stone fruit tested.
\end{abstract}

Additional keywords: aroma compounds, sensory evaluation

Brown rot is one of the main diseases in stone fruit $(7,32,34)$ and occurs both in the field and after harvest. Three species of Monilinia are recognized as causal agents of brown rot. Monilinia laxa (Aderhold \& Ruhland) Honey is the most common pathogen in European and South African growing areas. M. fructicola (G. Winter) Honey is the most important causal organism in North America, Australasia, Japan, and Brazil, whereas it is a quarantine organism in Europe. M. fructigena (Aderhold \& Ruhland) Honey occurs on both stone and pome fruit in Europe, but does not cause the extensive crop loss that $M$. laxa does. Losses are particularly severe if humidity, warm temperatures, and abundant rainfall prevail prior to harvest. $M$. laxa germination proceeds rapidly on wet fruit and is faster on ripening fruit than on fruit at pit hardening; in addition, germ tube growth is restricted when fruit are dry (18). The pathogen invades the fruit through wounds caused by insects or adverse weather and injuries caused by harvesting and handling operations. The co-

Corresponding author: F. Neri

E-mail: fiorella.neri@unibo.it

Accepted for publication 18 July 2006.

DOI: 10.1094/PD-91-0030

(C) 2007 The American Phytopathological Society nidia also can penetrate through microlesions, stomata, and lenticels of fruit skin (31). In some cases, infections occurring in the field remain quiescent until favorable conditions allow the pathogen to overcome host defenses, such that disease symptoms frequently develop during the postharvest phase. Postharvest losses are estimated to be 5 to $10 \%$ when postharvest fungicides are used; in countries where these treatments are not authorized, losses may reach $50 \%$ or more when favorable conditions are present (28).

In Italy, brown rot is controlled by fungicide spray programs in the field, whereas postharvest fungicide application is not allowed. The public demand to reduce the use of synthetic pesticides in the environment and the amount of chemical residues on fruit have stimulated the search for methods that are safe for humans. Among nonconventional treatments, several naturally occurring volatiles in the aroma component of fruit and vegetable products or in essential oils of spices and herbs have shown antimicrobial, antifungal, and insecticidal properties $(14,21,38)$. In addition, some of these compounds may play an interesting role in the control of defense gene expression, probably as a signal mediator within and between plants (17). Some studies on antifungal activity by plant aroma compounds against M. laxa or $M$. fructicola have been carried out in in vitro $(10,39,43)$ and in vivo trials (13). In other experiments, trans-2-hexenal (3$5,41)$ and citral $(11,35,39,40,45)$ have shown fungal inhibition against many fungal pathogens, but were not tested against M. laxa. The search for fumigants for postharvest disease control seems to be particularly interesting because of minimal handling and absence of wetting of fruit involved in vapor treatments.

The present study aimed to determine the efficacy of some plant volatiles against M. laxa in vitro and to test promising compounds as fumigants for postharvest treatments against brown rot in stone fruit.

\section{MATERIALS AND METHODS}

Volatile compounds. The aldehydes (hexanal, trans-2-hexenal, citral, transcinnamaldehyde, and $p$-anisaldehyde), the phenols (carvacrol and eugenol), and the ketones (2-nonanone and (-)-carvone) were screened for their ability to control M. laxa conidia germination and mycelial growth. The volatile compounds, as commercial preparations with at a nominal purity of least $95 \%$, were purchased from Sigma-Aldrich (Milan, Italy). The concentrations reported are expressed as liquid volume of volatile compound on filter paper per dish volume (in vitro) and as liquid volume of volatile compound in the flask per air volume inside the treatment apparatus (in vivo).

The pathogen. A monoconidial culture of M. laxa (isolate FF 34, from our collection) was grown on V8 agar (V8A; $250 \mathrm{ml}$ of V8 vegetable juice and $40 \mathrm{~g}$ of agar per $1,000 \mathrm{ml}$ of distilled water). Culture plates were incubated at $25^{\circ} \mathrm{C}$ under a photoperiod of $12 \mathrm{~h}$ of light and $12 \mathrm{~h}$ of dark for 10 to 14 days. For in vitro tests and fruit inoculation, conidial suspensions of M. laxa were prepared by washing the pathogen colonies with sterile distilled water containing $0.05 \%$ (vol/vol) Tween 80 . Spore concentrations were determined with a hemacytometer and adjusted to $10^{3} \mathrm{co}-$ nidia/ml.

In vitro experiments. The effect of the volatile compounds on conidial germination and mycelial growth of $M$. laxa was tested on malt extract agar, as described in a previous article (29). Liquid volumes of volatile compounds were added to $90-\mathrm{mm}$ paper filter placed on the cover inside the dish. The dishes then were covered quickly and wrapped in parafilm. At least five concentrations of compounds were tested and 
varied from 0.4 to $393.7 \mu \mathrm{l} /$ liter and from 3.1 to $984.2 \mu \mathrm{l} /$ liter for mycelial growth and conidial germination, respectively. Control treatments consisted of distilled water. For each treatment, for each compound at each of the concentrations tested, eight petri dishes (replications) were used. The number of germinated conidia and colony diameter were recorded after 3 and 7 days of incubation with volatile compounds, respectively. Minimum inhibitory concentration (MIC) was considered as the lowest concentration of the test compound at which no conidial germination or mycelial growth was observed. In turn, parafilm and filter papers were removed from the dishes and another assessment was carried out after 7 days at $20^{\circ} \mathrm{C}$ in order to evaluate whether the activity of the compounds was fungistatic or fungicidal. The experiments were performed twice.

Fruit. Apricot (cv. Tyrinthos), nectarine (cvs. Laura, Independence, Spring Bright, Stark Red Gold, and Weinberger), peach (cv. Elegant Lady), and plum (cvs. Angeleno, Blackamber, Black Gold, and TC Sun) fruit harvested at commercial maturity were purchased from the EmiliaRomagna Growers' Cooperative Intesa. Only visibly undamaged and disease-free fruit were used in the experiments. Fruit were stored at $0^{\circ} \mathrm{C}$ and used within 7 days after harvest.

Inoculation. Fruit were wounded with a sterile nail (one wound per fruit, in the equatorial zone, 2 by $2 \mathrm{~mm}$ ) and dipped for $1 \mathrm{~min}$ in a conidial suspension $\left(10^{3}\right.$ conidia/ml) of $M$. laxa prepared as described above. Inoculated fruit were kept for $1 \mathrm{~h}$ at room temperature $\left(20^{\circ} \mathrm{C}\right)$ before treatment with volatile compounds. The control was represented by nontreated fruit, wounded and inoculated as described above. Four replicates were used in each treatment and 26 fruit were used in each replication.

Effects of volatile compounds on brown rot control and fruit quality. Fruit were exposed to the vapor of the compounds in a cabinet with a capacity of 100 liters, as previously described (29). Treatments were performed at $20^{\circ} \mathrm{C}$ over a $24-\mathrm{h}$ period using the compounds that showed the best results in in vivo preliminary trials (data not reported). In order to find the concentration effective against brown rot and not phytotoxic to fruit, the following concentrations were tested: $5,10,20$, and $40 \mu \mathrm{l} /$ liter for trans-2-hexenal; 25, 50, and $100 \mu \mathrm{l} /$ liter for carvacrol; and 25, 50, and $200 \mu \mathrm{l} /$ liter for citral. After treatment, fruit were removed from the cabinet and kept at $20^{\circ} \mathrm{C}$ and $95 \%$ relative humidity. Nontreated fruit were closed in a cabinet at $20^{\circ} \mathrm{C}$ for $24 \mathrm{~h}$ with air circulation and then placed under the same conditions of temperature and humidity as treated fruit. The percentage of infected wounds was recorded 4 days after inoculation. All experiments were performed twice. The pos- sible phytotoxic response and the effect on fruit odor were examined both after treatments and after 3 days at $20^{\circ} \mathrm{C}$ following treatment (simulation of fruit market life at ambient temperature). Then, a 10-member, trained panel described and compared fruit odor of treated and nontreated fruit using an intensity scale increasing from 1 (= no off-odors) to 9 (= very strong off-odors). For trials in which no visible injuries occurred after exposure to trans-2-hexenal, the effect of treatment on fruit sensory traits (sweetness, sourness, fruitiness, offflavors, hardness, and juiciness) also was tested using fruit held for 3 days at $20^{\circ} \mathrm{C}$ following treatment. For the evaluation, 10 fruit from each treatment and the control were selected for homogenous firmness from samples of 26 noninoculated fruit. Firmness expressed as Newton was measured, after removing the skin, on opposite sides of each fruit using a Chatillon digital penetrometer fitted with an 8-mm fruit tester probe. The fruit were cut into six pieces and given to 10 tasters, each of whom assessed six pieces from different fruit. The samples, coded with three numbers, were presented at random one at a time. The tasters were instructed to rinse out their mouths with water between samples. Sensory profile was assessed using a nine-category scale. The intensity of the descriptors increased from 1 (= none) to 9 (= extreme) for juiciness, sweetness, sourness, fruitiness, off-odors, and off-flavors. For hardness, 1 = extremely hard and $9=$ extremely soft; for sweet-acid balance, $1=$ mainly sour, 5 = balanced, and $9=$ mainly sweet. Training of panelists and general testing conditions followed fundamental principles of good practice in sensory evaluation of food $(22,27)$.

Statistical analysis. For each volatile compound, the effective dose (ED) for 50 and $95 \%$ inhibition $\left(\mathrm{ED}_{50}\right.$ and $\mathrm{ED}_{95}$, respectively) was calculated using probitanalysis applied to the percentages of conidial germination and mycelial growth obtained from in vitro experiments. Regression lines between the logarithm of the compound concentrations and the effectiveness indices transformed in probit were calculated. The data from the in vivo experiments were combined based on Bartlett's Test, which indicated homogeneity. Means were separated using the least significant difference test at $P \leq 0.05$. The data were processed using the statistical package Statistica for Windows (StatSoft Italia srl, Padova, Italy).

\section{RESULTS}

In vitro experiments. The regression lines of the logarithm of the compound concentrations and the effectiveness indices transformed in probit, which were used to calculate the $\mathrm{ED}_{50}$ and $\mathrm{ED}_{95}$, were highly significant (correlation coefficients between 0.91 and 0.99 , confidence limits $95 \%, P \leq 0.01$; data not reported). The most active compounds against $M$. laxa were found to be trans-2-hexenal, carvacrol, and citral, and they inhibited either conidial germination or mycelial growth (Table 1). In particular, trans-2-hexenal was the best inhibitor of conidial germination $\left(\mathrm{ED}_{50}=7.5 \mu \mathrm{l} /\right.$ liter, $\mathrm{ED}_{95}=9.4 \mu \mathrm{l} /$ liter, and $\mathrm{MIC}=12.3 \mu \mathrm{l} /$ liter), whereas carvacrol was the best mycelial growth inhibitor $\left(\mathrm{ED}_{50}=2 \mu \mathrm{l} /\right.$ liter, $\mathrm{ED}_{95}=3.4 \mu \mathrm{l} /$ liter, and $\mathrm{MIC}=6.1 \mu \mathrm{l} /$ liter). Neither conidial germination nor mycelial growth was observed at $20^{\circ} \mathrm{C} 7$ days after the filter papers that were treated with trans-2-hexenal and carvacrol at the MIC level had been removed from the dishes. For citral, MIC for both conidial germination and mycelial growth was $24.6 \mu \mathrm{l} /$ liter; however, higher concentrations were required to inhibit the resumption of pathogen growth during the week after the treatment was removed (36.9 and $49.2 \mu \mathrm{l} /$ liter for mycelial growth and conidial germination, respectively,) Better inhibition against mycelial growth $(\mathrm{MIC}=24.6 \mu \mathrm{l} /$ liter and inhibition after the removal of treatment $=30.7 \mu \mathrm{l} /$ liter $)$ than against conidial germination ( $\mathrm{MIC}=$ $98.4 \mu \mathrm{l} /$ liter) was exhibited by transcinnamaldehyde. The opposite was found for hexanal and 2-nonanone, which exhib-

Table 1. Minimum inhibitory concentrations (MICs) and effective dose for 50 and $95 \%$ inhibition $\left(E D_{50}\right.$ and $\mathrm{ED}_{95}$, respectively; $\mu \mathrm{l} /$ liter) of the treatments with different volatile compounds measured by conidial germination and mycelial growth of Monilinia laxa

\begin{tabular}{|c|c|c|c|c|c|c|}
\hline \multirow[b]{2}{*}{ Compound } & \multicolumn{3}{|c|}{ Conidial germination $^{x}$} & \multicolumn{3}{|c|}{ Mycelial growth } \\
\hline & $\mathbf{E D}_{50}$ & $\mathbf{E D}_{95}$ & MIC & $\mathbf{E D}_{\mathbf{5 0}}$ & $\mathbf{E D}_{95}$ & MIC \\
\hline trans-2-Hexenal & 7.5 & 9.4 & $12.3^{y}$ & 23.0 & 28.3 & $36.9^{y}$ \\
\hline Carvacrol & 7.1 & 14.7 & $24.6^{\mathrm{y}}$ & 2.0 & 3.4 & $6.1^{\mathrm{y}}$ \\
\hline Citral & 11.4 & 19.3 & $24.6^{\mathrm{z}}$ & 5.2 & 13.3 & $24.6^{z}$ \\
\hline trans-Cinnamaldehyde & 5.0 & 23.7 & $98.4^{\mathrm{y}}$ & 9.7 & 17.3 & $24.6^{\mathrm{z}}$ \\
\hline Hexanal & 15.6 & 20.1 & $24.6^{\mathrm{z}}$ & 57.2 & 91.0 & $123.0^{\mathrm{y}}$ \\
\hline (-)-Carvone & 41.3 & 63.1 & $73.8^{\mathrm{z}}$ & 10.0 & 33.0 & $73.8^{z}$ \\
\hline Eugenol & 19.7 & 84.7 & $246.1^{\mathrm{y}}$ & 4.2 & 17.4 & $36.9^{y}$ \\
\hline 2-Nonanone & 33.6 & 43.6 & $49.2^{\mathrm{z}}$ & 47.1 & 132.6 & $393.7^{z}$ \\
\hline$p$-Anisaldehyde & 109.9 & 266.5 & $984.2^{y}$ & 71.5 & 213.6 & $295.3^{y}$ \\
\hline
\end{tabular}

${ }^{x}$ Fungicidal activity was evaluated 7 days after removal of parafilm and the filter paper containing the volatile compound. Means of 16 replicates.

${ }^{y}$ MICs that did not result in growth after removal of filter paper.

${ }^{\mathrm{z}}$ MICs that did result in growth after removal of filter paper. 
ited considerable inhibitory activity only with regard to conidial germination (MICs $=24.6$ and $49.2 \mu \mathrm{l} /$ liter, respectively). Moreover, higher concentrations of hexanal and 2-nonanone were needed to inhibit the resumption of conidial germination during the week after their removal from dishes: $196.8 \mu \mathrm{l} /$ liter for hexanal and $>147.6 \mu \mathrm{l} / \mathrm{liter}$ for 2-nonanone (data not determined). Eugenol showed consistent inhibition of mycelial growth at $36.9 \mu \mathrm{l} /$ liter, but only slight inhibition of conidial germination (MIC $=246.1 \mu \mathrm{l} /$ liter). (-)-Carvone inhibited both conidial germination and mycelial growth at $73.8 \mu \mathrm{l} /$ liter, whereas concentrations of 123 and $98.4 \mu \mathrm{l} /$ liter for conidial germination and mycelial growth, respectively, were needed to inhibit the regrowth of pathogen during the week after the removal of treatment. $p$-Anisaldehyde and 2nonanone were the least active compounds for restricting conidial germination and mycelial growth, respectively.
In vivo experiments. Treatment with trans-2-hexenal at $5 \mu \mathrm{l} /$ liter was found to be ineffective in brown rot control, and severe phytotoxicity resulted from treatment with $20 \mu \mathrm{l} /$ liter in apricot or with 40 $\mu \mathrm{l} /$ liter of trans-2-hexenal in peach and nectarine, stimulating the development of infections by $M$. laxa and Penicillium expansum on damaged tissues (data not reported). Hence, trans-2-hexenal concentrations of 10 or $20 \mu \mathrm{l} /$ liter were chosen for subsequent experiments. The most effective doses of trans-2-hexenal were 10 $\mu \mathrm{l} /$ liter in apricot (efficacy of $68.5 \%$ ) and $20 \mu \mathrm{l} /$ liter in peach, nectarine, and plum, with efficacy varying from $80.3 \%$ in cv. Weinberger to $46.2 \%$ in cv. Black Gold (Figs. 1 and 2). The only positive results with citral (40\% efficacy) or with carvacrol (32.9\% efficacy) were obtained on 'Spring Bright' nectarine at a rate for each compound of $50 \mu \mathrm{l} /$ liter (Table 2). Lower or higher concentrations of citral (25 and 200 $\mu \mathrm{l} /$ liter) and carvacrol (25 and $100 \mu \mathrm{l} /$ liter $)$ were not effective. In some cases, suberization of the epidermal tissues surrounding the wound was observed in fruit treated with trans-2-hexenal compared with nontreated controls, particularly for the highest concentrations of the compound.

Different fruit response to trans-2hexenal treatment was exhibited among stone fruit species (Table 3). No visible disorders were observed in plum fruit exposed to trans-2-hexenal at 10 or 20 $\mu \mathrm{l} /$ liter. In contrast, phytotoxic symptoms were induced in all cultivars of apricot, nectarine, and peach by treatment with trans-2-hexenal at $20 \mu \mathrm{l} /$ liter and in apricot $\mathrm{cv}$. Tyrinthos, nectarine cv. Weimberger, and peach cv. Elegant Lady by with the compound at $10 \mu \mathrm{l} /$ liter. Phytotoxicity caused by trans-2-hexenal consisted of irregular dark-yellow or brown surface blemishes in peach and nectarine, and dark orange blemishes in apricot. In Weinberger

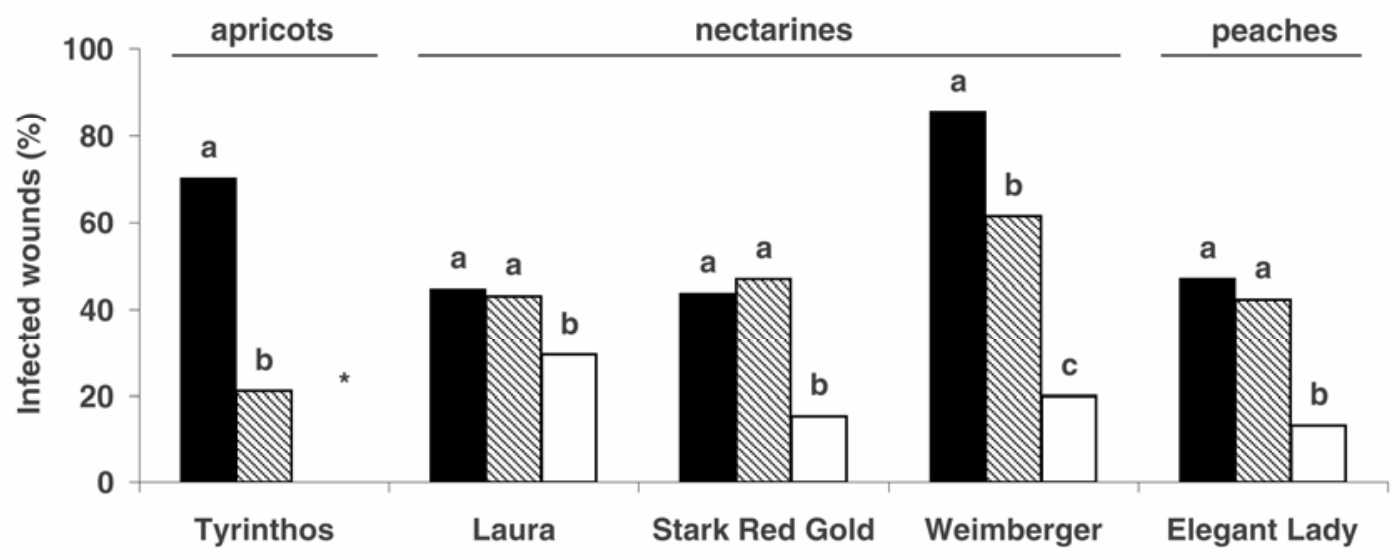

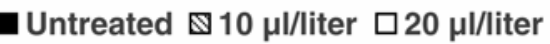

Fig. 1. Effect of trans-2-hexenal on brown rot control in apricot, nectarine, and peach. Fruit were wounded and inoculated with Monilinia laxa (10 ${ }^{3}$ spores $/ \mathrm{ml}$ ). Means are averaged values of two experiments, each containing four replicates of 26 fruit each per treatment. Disease was assessed 4 days after pathogen inoculation. Within each cultivar, means followed by different letters are significantly different according to the least significant difference test $(P \leq$ 0.05). Asterisk (*) indicates data were not recorded, due to the development of secondary infections on tissues damaged by treatment.

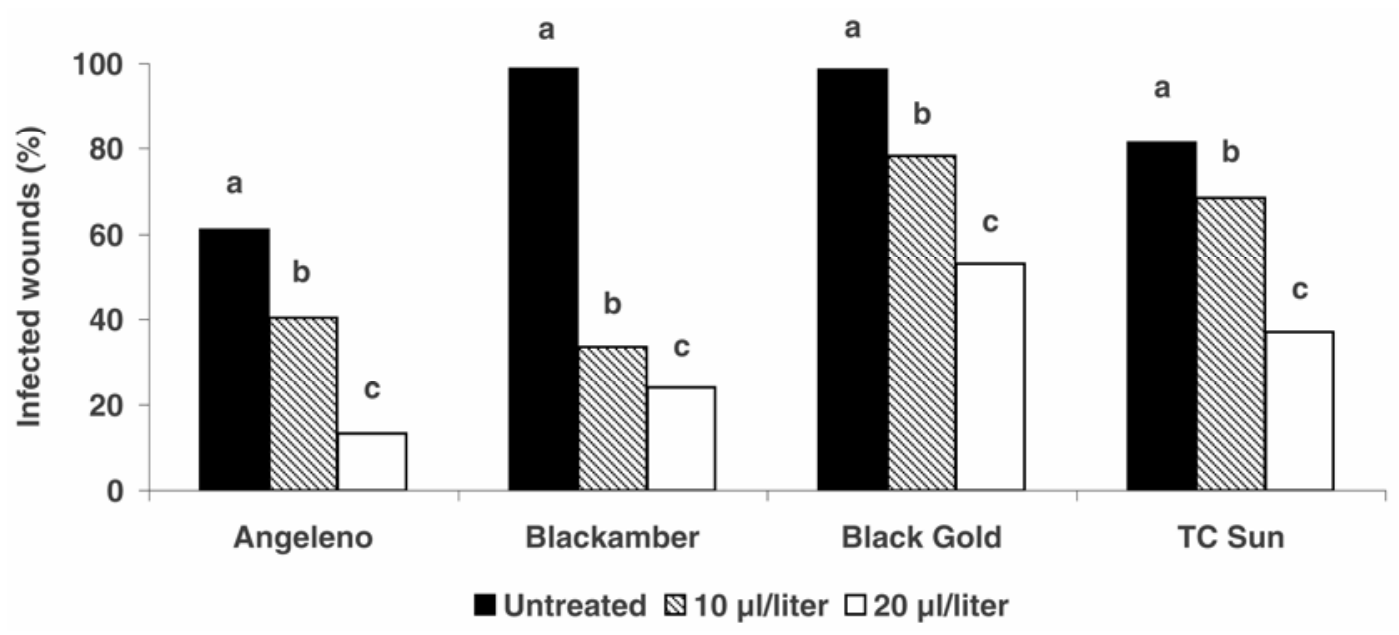

Fig. 2. Effect of trans-2-hexenal on brown rot control in plum. Fruit were wounded and inoculated with Monilinia laxa ( $10^{3}$ spores $\left./ \mathrm{ml}\right)$. Means are averaged values of two experiments, each containing four replicates of 26 fruit each per treatment. Disease was assessed 4 days after pathogen inoculation. Within each cultivar, treatments means followed by different letters are significantly different according to the least significant difference test $(P \leq 0.05)$. 
growth was more sensitive to the phenols carvacrol and eugenol and to the aromatic aldehydes trans-cinnamaldehyde and $p$ anisaldehyde than was conidial germination, whereas the opposite was found for the aliphatic aldehydes trans-2-hexenal and hexanal and the ketone 2-nonanone. A greater sensitivity of conidia than mycelia to trans-2-hexenal vapors also was found in B. cinerea (16).

Bioassay results confirmed the antifungal activity against $M$. laxa by trans-2hexenal vapor treatment $(20 \mu \mathrm{l} /$ liter in peach, nectarine, and plum and $10 \mu \mathrm{l} /$ liter in apricot), with efficacy varying from 42.6 to $97.1 \%$. Citral and carvacrol $(50 \mu \mathrm{l} / \mathrm{liter})$ showed moderate effects on the pathogen. In addition to the high reactivity of the compound, the antifungal activity of trans2-hexenal may be attributed to its volatility relative to that of citral and carvacrol. (12). In addition to a direct effect on the fungal pathogen, trans-2-hexenal may stimulate fruit defense mechanisms. Recent studies in Arabidopsis thaliana have shown that trans-2-hexenal treatment to control $B$. cinerea activates several defense-related genes, such as allene oxide synthase and lipoxygenase 2 (23). In addition, the treatment induces lignification of leaves, and accumulation of protein plant defensin 1.2 and pathogenesis-related protein 3 transcripts and camalexin (24). In our study, a suberization of the epidermal tissues surrounding the wound also was observed in some fruit treated with trans-2-hexenal compared with the control. The treatment probably stimulated wound repair mechanisms, acting as a physical barrier to the penetration of the M. laxa hyphae.

Compared with our previous studies $(29,30)$, stone fruit were found to be more sensitive to trans-2-hexenal injury than were pome fruit. A differential sensitivity to trans-2-hexenal also was observed among stone fruit species, increasing from plum, to nectarine and peach, to apricot. No phytotoxic effect was observed in plums treated with trans-2-hexenal at 10 or $20 \mu \mathrm{l} /$ liter. By contrast, the same concentrations caused phytotoxicity in most apricot, nectarine, and peach cultivars in the present study. Probably, more trans-2hexenal was absorbed by apricot, nectarine, and peach fruit than by plum fruit, causing differences in the aroma compound metabolism and in the phytotoxic response. As found in other studies on strawberry, blackberry, and grape $(4,5)$, trans-2-hexenal is absorbed and metabolized by fruit; however, the level of adsorption, the products of the metabolism, and the fruit sensitivity to the compound vary among fruit species and cultivars. In addition, trans-2-hexenal treatment using concentrations effective in brown rot control induced off-odors or off-flavors in all cultivars of stone fruit, and these problems persisted, although with less intensity, even after ripening.
The results obtained in this study showed a significant activity of trans-2hexenal vapor treatment in the control of $M$. laxa in in vitro and in vivo trials. The efficacy in brown rot control and the natural occurrence of trans-2-hexenal in many edible products, suggesting it has a low toxicity to humans, could make trans-2hexenal a potential postharvest biofumigant. However, the phytotoxic response found in apricot, nectarine, and peach makes practical application of trans-2hexenal vapor treatment on these fruit species difficult. In contrast, fumigation with trans-2-hexenal seems to be more promising in plum fruit, due to their higher tolerance to the compound, if treatment conditions that eliminate detrimental effects on sensory traits are found in further studies.

\section{ACKNOWLEDGMENTS}

This work was supported by the European Commission Project acronym ISAFRUIT, contract 016279/T5.4.1, and the Interregional Project Frutticoltura Post-raccolta no. 12.

\section{LITERATURE CITED}

1. Adams, S., Kunz, B., and Weidenborner, M. 1996. Mycelial deformations of Cladosporium herbarum due to the application of eugenol or carvacrol. J. Essent. Oil Res. 8:535-540.

2. Andersen, R. A., Hamilton-Kemp, T. R., Hildebrand, D. F, McCracken, C. T., Collins, R. W., and Fleming, P. D. 1994. Structureantifungal activity relationships among volatile $\mathrm{C}_{6}$ and $\mathrm{C}_{9}$ aliphatic aldehydes, ketones, and alcohols. J. Agric. Food Chem. 42:1563-1568.

3. Archbold, D. D., and Hamilton-Kemp, T. R. 2000. Aroma volatiles as modulators of postharvest mold development on fruit: in vivo role and fumigation tools. Acta Hortic. 518:87-92.

4. Archbold, D. D., Hamilton-Kemp, T. R., Barth, M. M., and Langlois, B. E. 1997. Identifying natural volatile compounds that control gray mold (Botrytis cinerea) during postharvest storage of strawberry, blackberry and grape. J. Agric. Food Chem. 45:4032-4037.

5. Archbold, D. D., Hamilton-Kemp, T. R., Clements, A. M., and Collins, R. W. 1999. Fumigating 'Crimson Seedless' table grapes with (E)-2-hexenal reduces mold during longterm postharvest storage. HortScience 34:705707.

6. Arras, G, and Usai, M. 2001. Fungitoxic activity of 12 essential oils against four postharvest citrus pathogens: chemical analysis of Thymus capitatus oil and its effect in subatmospheric pressure conditions. J. Food Prot. 64:1025-1029.

7. Batra, L. R. 1991. Pages 7-126 in: World Species of Monilinia (Fungi): Their Ecology, Biosystematics, and Control. Mycologia Memoir 16. J. Cramer, Berlin.

8. Berger, R. G. 1991. Fruits I. Pages 284-292 in: Volatile Compounds in Foods and Beverages. H. Maarse ed. Marcel Dekker, Inc., New York.

9. Boelens, M. H. 1991. Spices and condiments II. Pages 449-482 in: Volatile Compounds in Foods and Beverages. H. Maarse, ed. Marcel Dekker, Inc., New York.

10. Caccioni, D. R L., and Guizzardi, M. 1994. Inhibition of germination and growth of fruit and vegetable postharvest pathogenic fungi by essential oil components. J. Essent. Oil Res. 6:174-179.

11. Caccioni, D. R. L., Deans, S. G., and Ruberto, G. 1995. Inhibitory effect of citrus fruit essential oil components on Penicillium italicum and Penicillium digitatum. Petria 5:177-182.
12. Caccioni, D. R. L., Gardini, F., Lanciotti, R and Guerzoni, M. E. 1997. Antifungal activity of natural compounds in relation to their vapor pressure. Sci. Aliment. 17:21-34.

13. Caccioni, D. R. L., Tonini, G., and Guizzardi, M. 1995. Antifungal activity of stone fruit aroma compounds against Monilinia laxa (Aderh. Et Ruhl.) Honey and Rhizopus stolonifer (Ehrenb.): in vivo trials. J. Plant Dis. Prot. 102:518-525.

14. Cowan, M. M. 1999. Plant products as antimicrobial agents. Clin. Microbiol. Rev. 12:564582.

15. Croft, K. P. C., Jüttner, F,. and Slusarenko, A J. 1993. Volatile products of the lipoxygenase pathway evolved from Phaseolus vulgaris (L.) leaves inoculated with Pseudomonas syringae pv. phaseolicola. Plant Physiol. 101:13-24.

16. Fallik, E., Archbold, D. D., Hamilton-Kemp, T. R., Clements, A. M., and Collins, R. W. 1998. (E)-2-hexenal can stimulate Botrytis cinerea growth in vitro and on strawberries in vivo during storage. J. Am. Soc. Hortic. Sci. 123:875-881.

17. Farmer, E. E. 2001. Surface-to-air signals Nature 411:854-856.

18. Fourie, P. H., and Holz, G. 2003. Germination of dry, airborne conidia of Monilinia laxa and disease expression on nectarine fruit. Australas. Plant Pathol. 32:9-18.

19. Hamilton-Kemp, T. R., Archbold, D. D. Collins, R. W., and Yu, K. 2003. Emission patterns of wound volatile compounds following injury of ripe strawberry fruit. J. Sci. Food Agric. 83:283-288

20. Hatanaka, A. 1993. The biogeneration of green odour by green leaves. Phytochemistry 34:1201-1218.

21. Isaman, M. 2000. Plant essential oils for pest and disease management. Crop Prot. 19:603608.

22. Jellinek, G. 1985. General testing conditions, pages 23-36, 348-385 in: Sensory Evaluation of Food, Theory and Practice. Ellis Horwood Series in Food Science and Technology, Chichester, England.

23. Kishimoto, K., Matsui, K., Ozawa, R., and Takabayashi, J. 2005. Volatile- $\mathrm{C}_{6}$-aldehydes and allo-cimene activate defense genes and induce resistance against Botrytis cinerea in Arabidopsis thaliana. Plant Cell Physiol. 46:1093-1102.

24. Kishimoto, K., Matsui, K., Ozawa, R., and Takabayashi, J. 2006. Components of $\mathrm{C}_{6^{-}}$ aldehyde-induced resistance in Arabidopsis thaliana against necrotrophic fungal pathogen, Botrytis cinerea. Plant Sci. 170:715-723.

25. Kubo, A., Lunde, C. S., and Kubo, I. 1995 Antimicrobial activity of the olive oil flavor compounds. J. Agric. Food Chem. 43:16291633 .

26. Latrasse, A. 1991. Fruits III. Pages $333-340$ in: Volatile Compounds in Foods and Beverages. H. Maarse, ed. Marcel Dekker, Inc., New York.

27. Lawless, H. T., and Heymann, H. 1998. Principles of good practice. Pages 83-115 in: Sensory Evaluation of Food: Principles and Practices. Chapman \& Hall, International Thompson Publishing, New York.

28. Margosan, D. A., Smilanick, J. L., Simmons, G. F., and Henson, D. H. 1997. Combination of hot water and ethanol to control postharvest decay of peaches and nectarines. Plant Dis. 81:1405-1409.

29. Neri, F., Mari, M. and Brigati, S. 2006. Control of Penicillium expansum by plant volatile compounds. Plant Pathol. 55:100-105.

30. Neri, F., Mari, M., Menniti, A. M., and Brigati, S. 2006. Control of Penicillium expansum disease in pears and apples by trans-2-hexenal vapours. Postharvest Biol. Technol. 41:101108.

31. Nguyen-The, C., Hugueney, R., and Arnoux, M. 1989. Contribution à l'étude des voies de 
penetration de parasites fongiques des nectarines Monilia laxa (Ascomycète-Discomycète) et Rhizopus stolonifer (Zygomycète-Mucorale). Agronomie 9:271-276.

32. Ogawa, J. M., Zehr, E. I, and Biggs, A. R. 1995. Diseases caused by fungi. Pages $98-100$ in: Compendium of Stone Fruit Diseases. J. M. Ogawa, E. I. Zehr, G. W. Bird, D. F. Ritchie, K. Uriu, and J. K. Uyemoto, eds. American Phytopathological Society, St. Paul, MN.

33. Porretta, S. 2000. Pages 325-405 in: Analisi Sensoriale and Consumer Science. Chiriotti Editori, Pinerolo, Italy.

34. Pratella, G. C. 1996. La Moniliosi delle pesche: necessità di nuove strategie di difesa. Riv. Fruttic. Ortoflor. 7/8:71-74.

35. Rodov, V., Ben-Yehoshua, S., Fang, D. Q., Kim, J. J., and Ashkenazi, R. 1995. Preformed antifungal compounds of lemon fruit: citral and its relation to disease resistance. J. Agric. Food Chem. 43:1057-1061.
36. Shaw, P. E. 1991. Fruits II. Pages 305-327 in: Volatile Compounds in Foods and Beverages. H. Maarse, ed. Marcel Dekker, Inc., New York.

37. Thompson, D. P. 1996. Inhibition of growth of mycotoxigenic Fusarium species by butylated hydroxyanisole and/or carvacrol. J Food Prot. 59:412-415.

38. Tripathi, P., and Dubey, N. K. 2004. Exploitation of natural products as an alternative strategy to control postharvest fungal rotting of fruit and vegetables. Postharvest Biol. Technol. 32:235-245.

39. Tsao, R., and Zhou, T. 2000. Antifungal activity of monoterpenoids against postharvest pathogens Botrytis cinerea and Monilinia fructicola. J. Essent. Oil Res. 12:113-121.

40. Tsao, R., and Zhou, T. 2000. Interaction of monoterpenoids, methyl jasmonate, and $\mathrm{Ca}^{2+}$ in controlling postharvest brown rot of sweet cherry. HortScience 35:1304-1307.
41. Vaughn, S. F., Spencer, G. F., and Shasha, B. S. 1993. Volatile compounds from raspberry and strawberry fruit inhibit postharvest decay fungi. J. Food Sci. 58:793-796.

42. Whitfield, F. and Last, J. H. 1991. Vegetables. Pages 241-242 and 247-252 in: Volatile Compounds in Foods and Beverages. H. Maarse, ed. Marcel Dekker, Inc., New York.

43. Wilson, C. L., Franklin, J. D., and Otto, B. E. 1987. Fruit volatiles inhibitory to Monilinia fructicola and Botrytis cinerea. Plant Dis. 71:316-319.

44. Witerhalter, P. 1991. Fruits IV. Pages 389-390 and 394-395 in: Volatile Compounds in Foods and Beverages. H. Maarse, ed. Marcel Dekker, Inc., New York.

45. Wuryatmo, E., Klieber, A., and Scott, E. S 2003. Inhibition of citrus postharvest pathogens by vapor of citral and related compounds in culture. J. Agric. Food Chem. 51:26372640 . 